\title{
DESAIN DAN STRUKTUR ORGANISASI
}

Makalah ini disusun guna memenuhi tugas mata kuliah

"PENGANTAR MANAJEMEN"

Dosen Pembimbing :

Dra. Hj. Nuraeni Gani.M.M

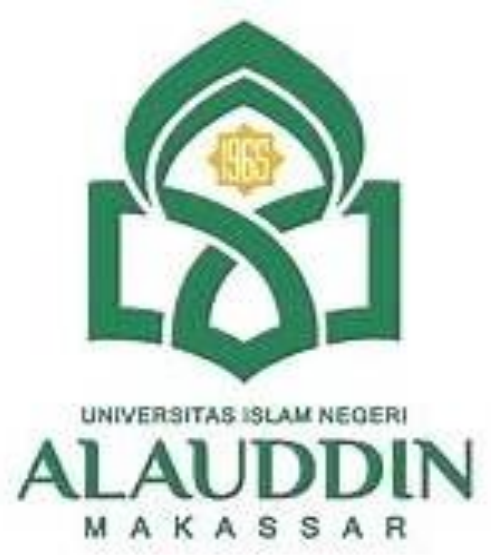

DISUSUN OLEH :

NURUL UYUN

90500121016

PRODI PERBANKAN SYARIAH

FAKULTAS EKONOMI DAN BISNIS ISLAM

UNIVERSITAS ISLAM NEGERI MAKASSAR

2021 M / 1443 


\section{KATA PENGANTAR}

Alhamdulillah, segala puja dan puji syukur kehadirat Allah swt. Yang telah memberikan kami kesehatan serta kesempatan sehingga kami bisa mengerjakan serta menyelesaikan makalah ini.

Shalawat serta salam semoga selalu terlimpah kepada Rasulullah Muhammad saw. yang telah menyampaikan risalah wahyu sebagai petunjuk untuk meraih kebahagiaan di dunia dan akhirat kelak.

Selanjutnya, terima kasih kami ucapkan kepada Ibu Dra. Hj. Nuraeni Gani.M.M

selaku dosen pembimbing mata kuliah "PENGANTAR MANAJEMEN" ini, atas bimbingannya. Alhamdulillah kami dapat menyelesaikan makalah ini meskipun masih banyak terdapat kekurangan di dalamnya. Karena itu, kritik dan saran sangat kami harapkan dalam upaya penyempurnaan makalah ini. Akhirnya, semoga makalah ini dapat memberi manfaat kepada kita semua. Amin.

Makassar, 12 November 2021

Nurul Uyun 


\section{DAFTAR ISI}

KATA PENGANTAR .................................................................................................................................................... ii

DAFTAR ISI............................................................................................................................................................ iii

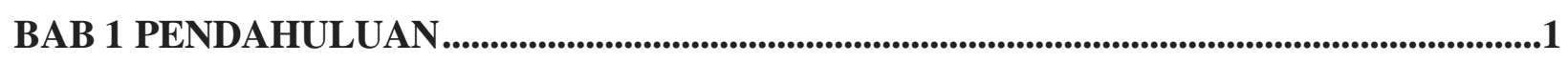

A. Latar Belakang...................................................................................................................................1

B. Rumusan Masalah .................................................................................................................1

C. Tujuan Makalah ............................................................................................................................... 1

BAB 2 PEMBAHASAN................................................................................................................... 2

A. Pengertian desain organisasi ................................................................................................2

B. pengertian struktur organisasi .............................................................................................. 2

C. Faktor-faktor yang mempengaruhi organisasi ...................................................................... 2

D. Empat pilar dalam pengorganisasian......................................................................... 3

E. Struktur organisasi formaldan informal...................................................................................................................

F. Hierarki vertikal dan horizontal................................................................................................................................. 4

G. Konsep dasar pengorganisasian ..............................................................................................................................4

H. Pendekatan dalam proses dapartementalisasi.............................................................................................4

BAB 3 PENUTUP ........................................................................................................................ 5

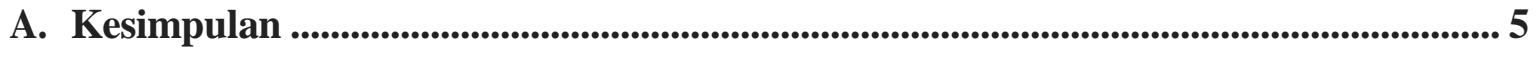

B. Saran ...............................................................................................................................................

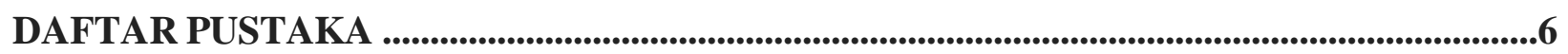




\section{BAB I}

\section{PENDAHULUAN}

\section{A. Latar Belakang}

Bagi sebuah perusahaan adanya Desain dan struktur organisasi sangat diperlukan. Terutama bagi mereka yang percaya bahwa bagan organisasi diperlukan guna menjamin manajemen yang efektif, akan menjadi bingung bila hal tersebut tidak ada. Individu tidak akan memahami pekerjaan mereka, apa yang harus dilakukan, bagaimana pekerjaan mereka akan bisa memenugi pekerjaan subunit lain.

Dengan tidak adanya bagan organisasi untuk mengklarifikasikan hubungan, maka hal yang tidak logik dan kekaburan akan terjadi. Kenyataannya, setiap proses dari pembuatan bagan organisasi merupakan tes yang baik bagi keberadaan bagian tersebut, karena setiap hubungan yang tidak bisa dibuatkan bagannya tampkanya akan menjadi kurang kuat dan karenanya membingungkan mereka yang bekerja di dalamnya.

Mereka yang mendukung dengan kuat percaya bahwa manajemen akan memilih desain dan struktur organisasi dengan spesifikasi tertulis atas persyaratan-persyaratan penting dari masing-masing tingkat manajemen, departemen, komite dan pekerjaan atau kelompok pekerjaan yang sama. Materi ini memberikan kepada kita individu dan kelompok informasi guna membantu memahami bagaimana usaha mereka berkorelasi dengan usaha pihak lain. Dibeberapa contoh, perusahaan kecil yang dapat berjalan dengan baik di tahap awal perkembangan mereka, mulai gagal bila pendirinya tidak bisa terus menerus memanajemeni dengan gaya pribadi mereka.

Transisi dari keberhasilan perusahaan kecil menjadi perusahaan besar yang berhasil, terganggu karena karyawan melakukan pekerjaan yang sesuai dengan kepribadian dan keterampilan khusus mereka dibanding dengan pekerjaan yang diperlukan utnuk kinerja organisasi. Bagan organisasi dan dokumen pendukung diperlukan dari saat awal keberadaan perusahaan, tidak hanya bila telah menjadi besar bagi satu orang untuk memanajemen.

Struktur organisasi dihasilkan dari keputusan manajerial mengenai empat atribut penting dari seluruh organisasi: pembagian kerja, dasar departementasi, ukuran departemen, dan pendelegasian wewenang. Keputusan yang dibuat manajer dipengaruhi oleh faktor desain pekerjaan dan desain organisasi seperti perbedaan individu, kompetensi tugas, teknologi, ketidakpastian lingkungan strategi, dan karakteristik manajer tertentu. Atribut struktur menentukan seberapa luas organisasi mencerminkan dimensi formal, kompleksitas dan sentralisasi. Struktur organisasi berkontribusi pada efektivitas organisasi dan hubungannya dalam menjustifikasi minat. 


\section{A. Rumusan Masalah}

1. Apa pengertian desain organisasi?

2. Apa pengertian struktur organisasi?

3. Apa faktor-faktor yang mempengaruhi organisasi?

4. Apa empat pilar dalam pengorganisasian?

5. Apa struktur organisasi formal dan informal?

6. Apa hierarki vertical dan horizontal?

7. Bagaimana konsep dasar pengorganisasian?

8. Bagaimana pendekatan dalam proses dapartementalisasi?

\section{B. TUJUAN}

1. Memenuhi tugas mata kuliah pengantar manajemen

2. Memahami tentang desan dan struktur organisasi

3. Memberikan ilmu kepada pembaca

4. Untuk menambah wawasan atau pemahaman terhadap pentingnya desain dan struktur organisasi 


\section{BAB II}

\section{PEMBAHASAN}

\section{A. Pengertian Desain Organisasi}

Desain organisasi adalah suatu model yang dipilih oleh organisasi untuk melakukan koordinasi dan pengendalian tugas-tugas dalam organisasi termasuk di dalamnya. Bagaimana seluruh anggota organisasi dimotivasi agar mengeluarkan segenap energy dan kemampuannya untuk memaksimalkan kemampuan dan sumber daya organisasi dalam memproses, menciptakan, menghasilkan sesuatu yang bernilai bagi organissasi baik barang maupun jasa. Jones (2001: 34-58) mengemukakan beberapa tentangan dalam mendesain organisasi yaitu: diferensiasi, diferensiasi integrasi, sentralisasi desentralisasi dan standarisasi penyesuaian bersama (mutual adjustmen). Tantangan tersebut dimaksudkan bahwa dalam desain organisasi senantiasa akan ditemui dua situasi yang dilematis antara dua kutub yang saling bersebrangan. Situasi tersebut mengharuskan pimpinan organisasi atau perusahaan melakukan pilihan-pilihan desain mana yang paling efektif, produktif, dan juga efisien bagi organisasinya. Setiap pilihan mempunyai konsekuensi-konsekuensi sesuai dengan kelebihan dan kekurangan masing-masing desain.

\section{B. Pengertian Struktur Organisasi}

Pada dasarnya, struktur organisasi adalah cara sesuatu disusun atau dibangun. Sedangkan organisasi adalah suatu wadah berkumpulnya minimal dua orang untuk mencapai sebuah tujuan. Sehingga, struktur organisasi adalah suatu susunan dan hubungan antara tiap bagian baik secara posisi maupun tugas yang ada pada perusahaan dalam menjalin kegiatan operasional untuk mencapai tujuan.

Struktur organisasi yang akan diibentuk tentunya struktur organisasi yang baik. Struktur organisasi yang baik harus memenuhi syarat sehat dan efisien. Struktur organisasi sehat berarti tiap-tiap satuan organisasi yang ada dapat menjalankan peranannya dengan tertib. Struktur organisasi efisien berarti dalam menjalankan peranannya tersebut masing-masing satuan organisasi dapat mencapai perbandingan terbaik antara usaha dan hasil kerja.

\section{Faktor-faktor yang Mempengaruhi Organisasi}

\section{Strategi Organisasi}

Pilihan struktur yang tepat belum menjamin kesuksesan dalam pencapaian tujuan, akan tetapi bisa meningkatkan kemungkinan sukses dalam pencapaian tujuan yang dibutuhkan adalah strategi dalam menjalankan suatu organisasi agar apa yang telah ditetapkan berjalan sesuai dengan yang diinginkan.

\section{Skala Organisasi}

Skala organisasi dapat dibedakan dari berbagai faktor, diantaranya adalah jumlah penjualan, pangsa pasar, hingga jumlah tenaga kerja. Organisasi yang berskala besar artinya organisasi tersebut memiliki cabang diberbagai daerah dikarenakan pangsa pasarnya yang luas. 


\section{Teknologi}

Faktor teknologi yang dimaksudkan adalah bagaimana suatu produk dari suatu organisasi bisnis dihasilkan atau juga dengan cara bagaimana pekerjaan dilakukan

\section{Lingkungan}

Faktor lingkungkan merupakan salah satu yang menentukan bagaimana organisasi akan berjalan. Lingkungan yang dinamis akan menuntut organisasi untuk menyesuaikan diri secara dinamis

\section{Empat Pilar Dalam Organisasi}

\section{Pilar Pertama: Pembagian Kerja (Division Of Work)}

Dalam perencanaan berbagai kegiatan atau pekerjaan untuk pencapaian tujuan tentunya telah ditentukan. Keseluruhan kegiatan dan pekerjaan yang telah direncanakan disederhanakan sedemikian rupa agar mempermudah pengimplementasiannya.

\section{Pilar Kedua: Pengelompokkan Pekerjaan}

Setelah dispesifikkan, maka kemudian pekerjaan tersebut dikelompokkan berdasarkan kriteria tertentu yang sejenis.

\section{Pilar Ketiga: Penentuan Relasi Antarbagian dalam Organisasi (Hierarchy)}

Setelah proses pengelompokkan, selanjutnya merupakan proses penentuan hierarki atau relasi antarbagian dalam suatu organisasi. Terdapat dua konsep penting dalam proses penentuan hierarki, yaitu :

$>$ Span of management yang terkait dengan jumlah orang atau bagian dibawah suatu departement yang bertanggung jawab kepada departement atau bagian tertentu.

$>$ Chain of command yang mengatur bagaiaman batasan kewenangan dibuat dan proses pelaporan setiap bagian kepada bagian tertentu.

\section{Pilar Keempat: Koordinasi}

Pilar terakhir dari proses pengorganisasian adalah koordinasi. Koordinasi adalah proses dalam mengintegrasikan seluruh aktivitas dari berbagai departemen atau bagian dalam organisasi agar tujuan organisasi bisa tercapai secara efektif dan efisien.

\section{E. Struktur dalam organisasi formal dan informal}

1. Struktur Organisasi Formal

Struktur ini merupakan struktur organisasi yang dihasilkan melalui keseluruhan proses. Struktur organisasi formal inilah yang biasanya dijadikan panduan oleh para anggota organisasi untuk melakukan berbagai hal dalam upaya pencapaian tujuan organisasi.

\section{Struktur Organisasi Informal}

Struktur ini merupakan struktur di mana para pekerja berkumpul secara berkelompok (diluar struktur formal) yang didasarkan pada kesamaan tuntutan, hobi, dan lain sebagainya. 


\section{F. Hienarki Vertikal Dan Horizontal}

Dalam penentuan hierarki span of management dan chain of command, manajer perlu mempertimbangkan akan menggunakan jenis hierarki yang bersifat vertikal atau horizontal.

1. Hierarki horizontal merupakan bentuk struktur organisasi yang bagian-bagian organisasinya banyak ke samping, dan meminimalkan jumlah sub-bagian atau departement.

2. Hierarki vertikal merupakan bentuk struktur organsisasi yang bagian-bagian organisasinya memperbanyak sub-bagian atau departement secara vertical

\section{G. Konsep dasar pengorganisasian}

Dalam proses pengorganisasian, manajer mengalokasikan keseluruhan sumber daya organisasi sesuai dengan rencana yang dibuat berdasarkan suatu kerangka kerja organisasi tertentu. Struktur organisasi pada dasarnya merupakan desain organisasi di mana manajer melakukan alokasi sumber daya, terutama yang terkait dengan pembagian kerja dan sumber daya yang dimiliki organisasi serta bagaiamana keseluruhan kerja tersebut dapat dikoordinasikan dan dikomunikasikan

\section{H. Pendekatan pada Proses Dapartemen Talisasi}

\section{Pendekatan Fungsional}

Berdasarkan pendekatan ini, proses departementalisasi dilakukan berdasarkan fungsifungsi tertentu yang mesti dijalankan dalam sebuah organisasi.

\section{Pendekatan Produk}

Pendekatan ini menjelaskan bahwa proses penentuan bagian-bagian dalam organisasi ditentukan berdasarkan jenis produk yang dihasilkan oleh organisasi.

3. Pendekatan Pelanggan

Pendekatan ketiga dalam departementalisasi adalah berdasarkan pelanggan atau customer departementalization. Berdasarkan pendekatan ini, penentuan bagian-bagian dalam organisasi ditentukan berdasarkan karakteristik pelanggan yang menjadi sasaran pelanggan dari organisasi.

4. Pendekatan Geografis

Berdasarkan pendekatan ini, penentuan bagian-bagian dalam organisasi ditentukan berdasarkan wilayah geografis di mana organisasi tersebut beroperasi.

\section{Pendekatan Matriks}

Pendekatan terakhir ini merupakan proses departementalisasi yang menggabungkan antara pendekatan fungsional dengan pendekatan lain berdasarkan proyek tertentu, produk tertentu, ataupun berdasarkan pendekatan lainnya. 


\section{BAB III}

\section{PENUTUP}

A. Kesimpulan

Desain organisasi adalah suatu model yang dipilih oleh organisasi untuk melakukan koordinasi dan pengendalian tugas-tugas dalam organisasi termasuk di dalamnya bagaimana seluruh anggota organisasi dimotivasi agar mengeluarkan segenap energy dan kemampuannya untuk memaksimalkan kemampuan dan sumber daya dalam memproses, menciptakan, menghasilkan sesuatu yang bernilai bagi organisasi baik barang maupun jasa. Stelah mendesain organisasi

termasuk pemilihan desain-desain yang akan diterapkan dalam organisasi, maka langkah selanjutnya adalah memilih dan menetapkan struktur organisasi.

\section{B. Saran}

Setelah membaca makalah ini, diharapkan para pembaca dapat memahami dan mengerti akan isi dan maksud dari judul tersebut diatas. Para pembaca bisa mendapatkan pelajaran serta dapat wawasan mmengenai "desain dan struktur organisasi". 


\section{DAFTAR PUSTAKA}

Ernie Tisnawati Sule dan Kurniawan Saefullah.2005.Pengantar Manajemen. jakarta:Indonesia Prenadamedia Group.

http://pengantarmanajemenfeuh.blongspot.com/2012/10/struktur-dan-desain-organisasi.html

http://www.scribd.com/doc/52181295/makalah-organisasi-manajemen 
